\title{
Locally adapted Brazilian ewes with different coat colors maintain homeothermy during the year in an equatorial semiarid environment
}

\author{
Jacinara Hody Gurgel Morais Leite ${ }^{1} \cdot$ Roberto Gomes Da Silva ${ }^{2} \cdot$ Wallace Sostene Tavares da Silva ${ }^{1}$. \\ Wilma Emanuela da Silva ${ }^{1} \cdot$ Renato Diógenes Macedo Paiva ${ }^{1}$ • José Ernandes Rufino Sousa ${ }^{1}$. \\ Luis Alberto Bermejo Asensio ${ }^{3}$. Débora Andrea Evangelista Façanha ${ }^{1}$
}

Received: 18 July 2017 / Revised: 10 May 2018 / Accepted: 12 May 2018 / Published online: 12 July 2018

(C) ISB 2018

\begin{abstract}
The present paper aimed to show the thermoregulatory responses of locally adapted Morada Nova sheep with different coat colors that were exposed to direct solar radiation in an equatorial semiarid region. Animals were classified into four groups according to the coat color as follows: (1) dark red, (2) intermediate red, (3) light red, and (4) white coats. Forty Morada Nova ewes were observed in for 7 consecutive months. The experimental variables measured were rectal temperature (RT), skin surface temperature (ST), respiratory rate (RR), skin surface evaporation (CE), respiratory evaporation (RE), and heat exchange by convection (HC) and radiation (R). Data were collected from 1100 to $1400 \mathrm{~h}$ after the animals were exposed to 30 min direct sunlight. The results showed that all groups maintained homeothermy. The $\mathrm{R}_{\mathrm{R}}$ was higher in the animals of groups 1 to 3 , which also showed higher values for ST when compared to the white-coated animals. Sensible heat exchange mechanisms were not important for heat loss, and $\mathrm{R}$ was a significant source of heat gain from the environment for the animals. Groups 1, 2, and 3 used RR more intensely than group $4(P$ value $=0.001)$; however, $C E$ was higher for the white-coated animals. It was concluded that Morada Nova sheep are well adapted to the semiarid environment, regardless of coat color.
\end{abstract}

Keywords Adaptation $\cdot$ Cutaneous evaporation $\cdot$ Equatorial semiarid $\cdot$ Homeothermy $\cdot$ Naturalized breed $\cdot$ Thermoregulatory mechanisms

\section{Introduction}

Global climate change has influenced the productivity of most domestic animals, especially those that are sensitive to environments with high temperatures and solar radiation levels, features easily found in tropical areas throughout the year (Silva et al. 2010). Thus, it is necessary to characterize the genetic resources and to understand all the mechanisms rela-

Jacinara Hody Gurgel Morais Leite

narinhazootecnista@hotmail.com

1 Universidade Federal Rural do Semi-Arido, UFERSA, Mossoró, RN, Brazil

2 Universidade Estadual Paulista, UNESP, Jaboticabal campus, São Paulo, Brazil

3 Universidad de La Laguna, San Cristobal de La Laguna, Santa Cruz de Tenerife, Canary Islands, Spain ted to the adaptability of these animals to the production system, especially grazing animals that are directly exposed to the environment (Mariante et al. 2005). In this context, it should be noted the Morada Nova sheep, the only breed locally acclimated to Northeastern Brazil, is characterized by a skin surface covered by hair, high prolificacy, rusticity, and good maternal ability (Facó et al. 2008; Lôbo et al. 2011). These animals are considered to be well adapted to semiarid conditions, but some aspects of the thermoregulatory processes that ensure their thermal balance with the environment need additional study.

Despite the recognized importance of these animals to the region, the number of farmers who have adopted the breed has been reduced over the years, and a warning has been given so the breed does not become at risk of extinction. The main problems affecting the expansion of this breed are related to the selection criteria, which are primarily focused on racial standards, regardless of characteristics related to productivity and physiological adaptation. Shiotsuki et al. (2016) reported that the current criteria for selection are reducing the genetic 
variability and influencing in a negative way the birth weight of Morada Nova lambs. According to the Brazilian Association of Sheep Breeders (ARCO), there are two subbreeds of the Morada Nova sheep, the white and the red. The latter sub-breed is the one most commonly used in livestock production systems. However, there are several tonalities of the red population of sheep, ranging from light to dark red. Breeders of the red sub-breed usually discard any animals with darker and lighter coat colors, a selection criterion that lacks any theoretical basis but that contributes to a significant negative impact on the genetic variability of the Morada Nova population. The white sub-breed has been sparsely adopted, and there are no more than five herds throughout the nation, which increases the risk of extinction of this valuable genetic resource. The reason behind these facts is a perceived low adaptation capability of the white animals to the semiarid environment; this reason has been challenged by recent studies (Costa et al. 2015).

The adaptability of an animal to a tropical environment is related to their ability to maintain an almost constant body temperature by means of heat dissipation via evaporation from both the body surface and the respiratory tract, even if the animals are exposed to high temperatures and solar radiation (McLean 1963; Gebremedhin et al. 1983; Silva 2008).

However, there is no available information about how much heat is gained by radiation or lost by cutaneous or respiratory evaporation by animals with different coat colors. There are two questions: (a) What are the possible differences between the thermoregulatory responses of the selected and the discarded animals as pertains to their coat color? (b) Is the white-coated population, in fact, less well adapted than the red-coated population? The answers to those questions are of great importance to guide selection for better-acclimated animals.

The present study was developed with the aim of evaluating the thermoregulatory responses of Morada Nova sheep of different coat colors. This study provides information that contributes to the selection of thermotolerant animals that perform well in the extensive production system in the Caatinga region, making the breed more attractive and assisting their conservation and improvement.

\section{Materials and methods}

The experiment (approved by the University Ethics Committee on the use of animals, CEUA-UFERSA, number 23091003895/2014-71) was carried out in three commercial flocks under equatorial semiarid environmental conditions in Morada Nova and Quixeramobim in the State of Ceará, Brazil. Table 1 shows the geographical positions and quantity of data collected in each flock. The data were recorded once a month from April (rainy season) to October (dry season) in each flock. Measurements were taken between 1100 and $1400 \mathrm{~h}$ after animals were exposed to $30 \mathrm{~min}$ of direct sunlight.

There were 40 Morada Nova ewes in each flock, with an average age of 3 years that were non-pregnant and non-lactating, with body weight averages of $28.46,27.4$, and $35.3 \mathrm{~kg}$ in flocks 1,2 , and 3 , respectively. The animals were managed on open pasture with native vegetation of the semiarid region. The animals were divided into four groups according to coat color, as follows: Group 1 (dark-red animals, $N=23$ ), group 2 (animals with intermediate red color; $N=27$ ), group 3 (lightred animals, $N=30$ ), and group 4 (white-coated animals, $N=$ 40 ). All the animals were clinically examined and checked for good health before sampling.

Environmental and physiological variables were recorded simultaneously in the same location. Dry and wet-bulb temperatures $\left(\mathrm{T}_{\mathrm{A}}\right.$ and $\left.\mathrm{T}_{\mathrm{W}},{ }^{\circ} \mathrm{C}\right)$ were obtained with a ventilated psychrometer, and the partial vapor pressure $(\mathrm{Pp}, \mathrm{kPa})$ was calculated. Black globe temperature $\left(\mathrm{Tg},{ }^{\circ} \mathrm{C}\right)$ was taken by a $15-\mathrm{cm}$ diameter copper black globe positioned in the same location as the animals. Wind speed was registered with a digital anemometer LUTRON AM-4201 ( $\left.\mathrm{W} \mathrm{m} \mathrm{s}^{-1}\right)$. The mean radiant temperature $\left(\mathrm{MRT},{ }^{\circ} \mathrm{C}\right)$ of the environment was obtained from $\mathrm{T}_{\mathrm{G}}$ and used to obtain the radiant heat load (RHL, $\mathrm{W} \mathrm{m}^{-2}$ ) according to Silva (2008). Average values of those measurements are shown in Table 2.

To improve the statistical analyses, the RHL values were grouped into five classes as follows: class $1(<500$ to $600 \mathrm{~W} \mathrm{~m}^{-2}$ ), class $2\left(>600\right.$ to $700 \mathrm{~W} \mathrm{~m}^{-2}$ ), class 3 (> 700 to $800 \mathrm{~W} \mathrm{~m}^{-2}$ ), class 4 (>800 to $900 \mathrm{~W} \mathrm{~m}^{-2}$ ), and class 5 (> $900 \mathrm{~W} \mathrm{~m}^{-2}$ ).

Rectal temperature $\left(\mathrm{RT},{ }^{\circ} \mathrm{C}\right)$ was measured with a digital clinical thermometer inserted into the rectum of each animal. The respiratory rate (RR, breaths/min) was recorded by counting flank movements. Coat surface temperature (ST, ${ }^{\circ} \mathrm{C}$ ) was measured by using an infrared thermometer (MasTec Dt 8550). The coat surface temperature was taken prior to the measurement of cutaneous evaporation.

Cutaneous evaporation $\left(\mathrm{CE} ; \mathrm{W} \mathrm{m}^{-2}\right.$ ) was measured with a ventilated capsule coupled to a tube containing moisture absorbent (silica). At the end of the process, the amount of evaporated water was quantified, which was then used to estimate $\mathrm{CE}$ by using the following equation:

$\mathrm{CE}={ }^{X \lambda} /{ }_{\mathrm{AA} T} \quad \mathrm{~W} \mathrm{~m}^{-2}$

where $\mathrm{CE}$ is the cutaneous evaporation $\left(\mathrm{W} \mathrm{m}^{-2}\right) ; X$ is the water lost by sweating $(\mathrm{g})$, obtained as the weight difference of the silica before and after the animal was evaluated; $\lambda=$ $2500.7879-2.3737 t_{A}$ is the latent heat of vaporization of water $\left(\mathrm{J} \mathrm{g}^{-1}\right)$; AA is the capsule area in contact with the animal's skin $\left(A=0.002123 \mathrm{~m}^{2}\right)$; and $T$ is the contact time of the capsule with the body surface ( $90 \mathrm{~s})$. 
Table 1 Geographical position and numbers of animals and recorded data

\begin{tabular}{lllllll}
\hline Location & Herd & Latitude & Longitude & Altitude $(\mathrm{m})$ & Number of sheep & $\begin{array}{l}\text { Number of data } \\
\text { points }\end{array}$ \\
\hline Morada Nova & 1 & $5^{\circ} 04^{\prime} 17^{\prime \prime}$ & $38^{\circ} 23^{\prime} 40^{\prime \prime}$ & 115 & 40 & 250 \\
Morada Nova & 2 & $5^{\circ} 09^{\prime} 02^{\prime \prime}$ & $38^{\circ} 18^{\prime} 29^{\prime \prime}$ & 39 & 40 & 270 \\
Quixeramobim & 3 & $5^{\circ} 04^{\prime} 74^{\prime \prime}$ & $39^{\circ} 51^{\prime} 73^{\prime \prime}$ & 173 & 40 & 248 \\
\hline
\end{tabular}

To calculate the heat lost by respiratory evaporation (RE; $\mathrm{W} \mathrm{m}^{-2}$ ), the method described by Silva et al. (2002) was used:

$$
\mathrm{RE}=\lambda \rho^{-1} m(\Psi \mathrm{EXP}-\Psi A) / A \quad\left(\mathrm{~W} \mathrm{~m}^{-2}\right)
$$

where $A\left(\mathrm{~m}^{2}\right)$ is the body surface area of the animal, which is estimated as $A=0.6265 e^{0.013 \mathrm{P}}$, where $P$ is body weight of the animal $(\mathrm{kg}) ; \lambda$ is the latent heat of vaporization of water $\left(\mathrm{J} \mathrm{g}^{-1}\right) ; \rho$ is the air density $\left(\mathrm{g} \mathrm{m}^{-3}\right)$; and $\mathrm{m}$ is the mass flow rate $\left(\mathrm{g} \mathrm{s}^{-1}\right)$, estimated as $\mathrm{m}=V_{R C} \rho\left(\frac{R R}{60}\right)\left(\mathrm{g} \mathrm{s}^{-1}\right)$, where $\mathrm{V}_{\mathrm{RC}}$ is the tidal volume, obtained according to Silva et al. (2002) and $\mathrm{RR}$ is respiratory rate (breath $\mathrm{min}^{-1}$ ).
The absolute humidity of the atmosphere $\left(\Psi \mathrm{A}, \mathrm{g} \mathrm{m}^{-3}\right)$ and of the exhaled air $\left(\Psi_{\mathrm{EXP}}, \mathrm{g} \mathrm{m}^{-3}\right)$, was given by:

$$
\begin{aligned}
\Psi \mathrm{A} & =2166.87 \mathrm{P}_{\mathrm{P}}\left\{\mathrm{T}_{\mathrm{A}}\right\} / \mathrm{T}_{\mathrm{A}} \text { and } \Psi_{\mathrm{EXP}} \\
& =2166.87 \mathrm{P}_{\mathrm{S}}\left\{\mathrm{T}_{\mathrm{EXP}}\right\} / \mathrm{T}_{\mathrm{EXP}}
\end{aligned}
$$

where $\mathrm{P}_{\mathrm{P}}\left\{\mathrm{T}_{\mathrm{A}}\right\}$ is the partial vapor pressure (kPa) of the ambient air, and $\mathrm{P}_{\mathrm{S}}\left\{\mathrm{T}_{\mathrm{EXP}}\right\}$ is the saturation pressure of the exhaled air; and $\mathrm{T}_{\mathrm{A}}$ is air temperature $\left({ }^{\circ} \mathrm{K}\right)$, and $\mathrm{T}_{\mathrm{EXP}}$ is the exhaled air temperature $\left({ }^{\circ} \mathrm{K}\right)$. The $\mathrm{T}_{\mathrm{EXP}}$ was determined according to Silva et al. (2002) specifically for sheep.
Table 2 Means of environmental variables in each herd during the

\begin{tabular}{|c|c|c|c|c|c|c|}
\hline Month & $\mathrm{T}_{\mathrm{A}}\left({ }^{\circ} \mathrm{C}\right)$ & $\mathrm{T}_{\mathrm{G}}\left({ }^{\circ} \mathrm{C}\right)$ & $\mathrm{W}(\mathrm{m} / \mathrm{s})$ & $\mathrm{P}_{\mathrm{p}}(\mathrm{KPa})$ & RHL (W m ${ }^{-2}$ ) & $\mathrm{P}(\mathrm{mm})$ \\
\hline \multicolumn{7}{|l|}{ Herd 1} \\
\hline April & 30.2 & 37.8 & 0.6 & 2.8 & 609.2 & 19.5 \\
\hline May & 31.4 & 41.3 & 0.6 & 2.9 & 666.5 & 0.0 \\
\hline June & 34.3 & 43.6 & 0.5 & 2.5 & 659.8 & 21.0 \\
\hline July & 33.6 & 48.5 & 1.4 & 2.2 & 869.6 & 0.0 \\
\hline August & 32.9 & 48.7 & 1.6 & 1.9 & 917.1 & 0.0 \\
\hline September & 34.7 & 52.5 & 1.3 & 1.2 & 909.5 & 0.0 \\
\hline October & 34.3 & 49.1 & 1.7 & 1.7 & 927.7 & 0.0 \\
\hline Means & 33.2 & 46.2 & 1,1 & 1.9 & 798.6 & - \\
\hline \multicolumn{7}{|l|}{ Herd 2} \\
\hline April & 32.2 & 43.0 & 1.4 & 2.8 & 767.6 & 85.4 \\
\hline May & 31.7 & 39.9 & 1.6 & 2.5 & 709.3 & 5.0 \\
\hline June & 33.1 & 44.2 & 1.9 & 2.4 & 766.3 & 44.0 \\
\hline July & 31.9 & 42.4 & 0.5 & 3.1 & 667.9 & 10.0 \\
\hline August & 32.9 & 45.1 & 0.5 & 1.6 & 772.8 & 0.0 \\
\hline September & 34.1 & 48.7 & 0.6 & 1.2 & 817.1 & 0.0 \\
\hline October & 33.9 & 48.5 & 0.9 & 1.3 & 816.8 & 0.0 \\
\hline Means & 33.7 & 47.5 & 0.9 & 2.5 & 800.9 & - \\
\hline \multicolumn{7}{|l|}{ Herd 3} \\
\hline April & 30.6 & 41.1 & 1.3 & 2.9 & 707.8 & 52.5 \\
\hline May & 30.4 & 40.0 & 1.3 & 2.9 & 747.2 & 27.5 \\
\hline June & 31.5 & 41.1 & 0.5 & 2.7 & 669.5 & 21.0 \\
\hline July & 31.9 & 47.4 & 1.0 & 1.9 & 886.4 & 8.0 \\
\hline August & 32.2 & 43.9 & 1.5 & 1.7 & 795.8 & 0.0 \\
\hline September & 31.2 & 38.2 & 1.3 & 1.6 & 652.8 & 0.0 \\
\hline October & 33.9 & 45.8 & 2.7 & 1.1 & 870.1 & 0.0 \\
\hline Means & 31.7 & 42.9 & 1.4 & 2.3 & 761.9 & - \\
\hline
\end{tabular}
experimental period in a semiarid region
$T_{A}$ air temperature, $T_{G}$ Black globe temperature, $W$ wind speed, $P p$ partial air vapor pressure, $R H L$ radiant heat load, $P$ pluviometry, reported by FUNCEME 
The rate of convective heat flow from the coat surface to the surrounding air is given by the equation:

$$
\mathrm{HC}=\frac{\rho c_{p}\left(S T-T_{A}\right)}{r_{\mathrm{H}}} \quad \mathrm{W} \mathrm{m}^{-2}
$$

where $\mathrm{T}_{\mathrm{A}}$ and $\mathrm{ST}$ are the air and coat surface temperatures, respectively, while $r_{\mathrm{H}}\left(\mathrm{S} \mathrm{m}^{-1}\right)$ is the boundary layer resistance to convective heat transfer.

$r_{\mathrm{H}}=\frac{\rho c_{p} d}{k N_{u}} \quad \mathrm{~s} \mathrm{~m}^{-1}$

where $d(\mathrm{~m})$ is the characteristic dimension of the body that was estimated as the square root of the body surface area, determined from the body weight $\mathrm{P}(\mathrm{kg})$ as $A_{S}=0.171 P^{0.503}$ after Bennett (1973); $\rho\left(\mathrm{g} \mathrm{m}^{-3}\right)$ is the density; $c_{\rho}\left(\mathrm{J} \mathrm{g}^{-1} \mathrm{~K}^{-1}\right)$ the specific heat; and $\kappa\left(\mathrm{W} \mathrm{m}^{-1} \mathrm{~K}^{-1}\right)$ is the thermal conductivity of the air (Silva 2008). The Nusselt number $\left(\mathrm{N}_{\mathrm{U}}\right)$ was estimated for a horizontal cylinder by the Churchill and Bernstein (1977) equation; Reynolds, Prandtl, and Grashof numbers were obtained as given by Silva (2008).

The heat exchange by radiation was estimated by following equation:

$R=\frac{\rho C_{P}(\mathrm{ST}-\mathrm{MRT})}{r_{R}} \quad \mathrm{~W} \mathrm{~m}^{-2}$

where ST and MRT are body surface temperature $\left({ }^{\circ} \mathrm{K}\right)$ and the mean radiant temperature $\left({ }^{\circ} \mathrm{K}\right)$.

$r_{R}=\frac{\rho c_{p}}{4 \varepsilon \sigma T m^{3}}$

where $\varepsilon$ is the emissivity thermal radiation of the surface of the animal, $\varepsilon=0$.98. The $\sigma$ is the Stefan-Boltzmann constant, $\sigma=$ $5.67051 \times 10^{-8} \mathrm{~W} \mathrm{~m}^{-2} \mathrm{k}^{-1}$. The Tm $=0.5(\mathrm{ST}+\mathrm{MRT})$.

Analyses of variance were performed by PROC MIXED (SAS), with time as a repeated measure and the analyzed effects were month, coat color, radiant heat load class, and the interaction between coat color and RHL. Logistic regression was used to determine the responses of animals with different colors of coats, with categorized values for rectal temperature, where $0=$ within normal range between 38.3 and $39.9{ }^{\circ} \mathrm{C}$ (Swenson and Reece 1996) and $1=$ outside normal range. Respiratory rates were classified in $0=$ animals that had approximately $40-60$ breaths per minute and $1=$ for animals with RRs above 60 breaths per minute (Silanikove 2000).

\section{Results and discussion}

Table 2 shows the overall means of the environmental variables. The average air temperature $\left(\mathrm{T}_{\mathrm{A}}\right)$ was above $30{ }^{\circ} \mathrm{C}$ throughout the experimental period, in all the flocks. This finding confirms that the animals were exposed to stressful environmental conditions throughout the experimental period. Bianca and Kunz (1978) related that thermal comfort zone for sheep between 20 and $30{ }^{\circ} \mathrm{C}$. The lowest average $\left(30.2^{\circ} \mathrm{C}\right)$ was recorded in April and the highest one $\left(34.7^{\circ} \mathrm{C}\right)$ in September, above that critical temperature for adult sheep related by Hahn (1985). Sevi et al. (2002) showed a marked reduction of milk yield in ewes, after prolonged exposure to mean ambient temperatures of $30^{\circ} \mathrm{C}$.

The radiant heat load (RHL, $\mathrm{W} \mathrm{m}^{-2}$ ) is closely related to the exchange by radiation between the animal and the environment. The values recorded in the present study were high for the three flocks in every month, with higher averages in August, when the dry season begins. Silva (2008) reported that low values of RHL are ideal. The RHL and $\mathrm{T}_{\mathrm{A}}$ recorded are typical for low latitudes, which shows little variation in solar radiation and air temperature levels throughout the year; in fact, regions of higher latitudes show a greater variation among seasons. However, less well-adapted animals require environmental management to ensure their survival, high reproductive efficiency, and consequently, good productivity rates, because prolonged heat stress can cause changes in animal health and have adverse effects on production and reproduction rates (Marai et al. 2007; Broucek et al. 2009). Morais et al. (2008) evaluated the heat stress of animals raised in semiarid environment and realized that in the warmer months, RHL reached values of approximately $801.47 \mathrm{~W} \mathrm{~m}^{-2}$, which resulted in increased rectal temperatures and respiratory rates.

There was significant difference among animals in relation to coat color, such that animals with the red coat color, regardless of the type of red color, had higher rectal temperatures (RT), respiratory rates (RRs), and respiratory evaporation (RE) and had less cutaneous evaporation (CE) and heat loss by convection (HC); red-coated sheep gained less heat by thermal radiation than white-coated animals (Table 3). The thermoregulatory responses were not affected by the tonality of the coat color, and the differences were found in relation to the sub-breed.

The average rectal temperature (RT) showed little variation in relation to the month (Table 3), remaining within a normal range for sheep (Swenson and Reece 1996), indicating that the thermoregulatory mechanisms triggered by the animals balanced the environmental stress to which they were exposed. The lowest average $\left(39.2{ }^{\circ} \mathrm{C}\right)$ was recorded in July and October; however, the highest one $\left(39.5^{\circ} \mathrm{C}\right)$ was recorded in April. Despite the small difference of $0.3{ }^{\circ} \mathrm{C}$, the highest average RT observed in the rainy season can be attributed to the lower average respiratory rate (RR) and respiratory evaporation (RE) that were also observed in this period, thus resulting in less heat dissipation by respiration, which is considered to be the main heat loss mechanism of panting species (Hales and Webster 1967). This agrees with Santos et al. (2006) and 
Table 3 Means and standard errors of rectal temperature (RT), respiratory rate (RR), heat loss by cutaneous (CE) and respiratory evaporation (RE), heat loss by convection (HC), and thermal radiation heat gain (HR) per month and tonality of coat in Morada Nova sheep under semiarid conditions

\begin{tabular}{lllllll}
\hline Effect & $\mathrm{RT}\left({ }^{\circ} \mathrm{C}\right)$ & $\mathrm{RR}(\mathrm{mpm})$ & $\mathrm{RE}\left(\mathrm{W} \mathrm{m}{ }^{-2}\right)$ & $\mathrm{CE}\left(\mathrm{W} \mathrm{m}{ }^{-2}\right)$ & $\mathrm{HC}\left(\mathrm{W} \mathrm{m}^{-2}\right)$ & $\mathrm{HR}\left(\mathrm{W} \mathrm{m}{ }^{-2}\right)$ \\
\hline Tonality of coat & & & & & & \\
Dark & $39.3^{\mathrm{ab}} \pm 0.06$ & $93^{\mathrm{a}} \pm 3.3$ & $26.62^{\mathrm{a}} \pm 0.3$ & $225.1^{\mathrm{b}} \pm 4.5$ & $7.4^{\mathrm{b}} \pm 0.9$ & $228.9^{\mathrm{b}} \pm 2.1$ \\
Intermediate & $39.4^{\mathrm{a}} \pm 0.06$ & $93^{\mathrm{a}} \pm 3.1$ & $26.3^{\mathrm{a}} \pm 0.2$ & $222.9^{\mathrm{b}} \pm 4.8$ & $6.2^{\mathrm{b}} \pm 0.8$ & $230.7^{\mathrm{b}} \pm 2.0$ \\
Light & $39.4^{\mathrm{a}} \pm 0.05$ & $92^{\mathrm{a}} \pm 2.9$ & $26.5^{\mathrm{a}} \pm 0.2$ & $217.1^{\mathrm{b}} \pm 4.6$ & $7.8^{\mathrm{b}} \pm 0.8$ & $229.8^{\mathrm{b}} \pm 1.9$ \\
White & $39.2^{\mathrm{b}} \pm 0.005$ & $65^{\mathrm{b}} \pm 2.8$ & $27.5^{\mathrm{b}} \pm 0.2$ & $269.3^{\mathrm{a}} \pm 4.6$ & $11.7^{\mathrm{a}} \pm 0.8$ & $252.6^{\mathrm{a}} \pm 1.9$ \\
Month & & & & & & \\
April & $39.5^{\mathrm{a}} \pm 0.05$ & $79^{\mathrm{b}} \pm 3.5$ & $24.7^{\mathrm{d}} \pm 0.3$ & $243.1^{\mathrm{b}} \pm 6.7$ & $7.4^{\mathrm{ab}} \pm 1.2$ & $242.9^{\mathrm{a}} \pm 2.6$ \\
May & $39.4^{\mathrm{a}} \pm 0.05$ & $81^{\mathrm{b}} \pm 3.3$ & $24.3^{\mathrm{d}} \pm 0.2$ & $292.4^{\mathrm{a}} \pm 6.3$ & $6.3 \mathrm{~b}^{\mathrm{bc}} \pm 1.1$ & $223.6^{\mathrm{c}} \pm 2.4$ \\
June & $39.3^{\mathrm{b}} \pm 0.05$ & $96^{\mathrm{a}} \pm 3.2$ & $26.7^{\mathrm{c}} \pm 0.2$ & $245.1^{\mathrm{b}} \pm 6.1$ & $5.7^{\mathrm{c}} \pm 1.0$ & $229.7^{\mathrm{b}} \pm 2.3$ \\
July & $39.2^{\mathrm{c}} \pm 0.04$ & $82^{\mathrm{b}} \pm 3.2$ & $27.9^{\mathrm{b}} \pm 0.2$ & $240.4^{\mathrm{b}} \pm 5.9$ & $8.2^{\mathrm{c}} \pm 1.1$ & $234.8^{\mathrm{b}} \pm 2.3$ \\
August & $39.3^{\mathrm{b}} \pm 0.05$ & $78^{\mathrm{b}} \pm 3.3$ & $29.3^{\mathrm{a}} \pm 0.2$ & $220.2^{\mathrm{c}} \pm 6.3$ & $11.1^{\mathrm{a}} \pm 1.1$ & $235.6^{\mathrm{b}} \pm 2.4$ \\
September & $39.4^{\mathrm{a}} \pm 0.05$ & $92^{\mathrm{a}} \pm 3.3$ & $26.4^{\mathrm{c}} \pm 0.2$ & $193.2^{\mathrm{d}} \pm 6.3$ & $5.7^{\mathrm{c}} \pm 1.1$ & $242.6^{\mathrm{a}} \pm 2.4$ \\
October & $39.2^{\mathrm{c}} \pm 0.05$ & $91^{\mathrm{a}} \pm 3.5$ & $27.8^{\mathrm{b}} \pm 0.3$ & $200.8^{\mathrm{d}} \pm 6.6$ & $11.6^{\mathrm{a}} \pm 1.1$ & $239.2^{\mathrm{ab}} \pm 2.5$ \\
\hline
\end{tabular}

Means with the same superscript, for each effect and within the each column, do not differ statistically $(P>0.05)$
Correa et al. (2012) that report an impaired by difficult in heat dissipation due to associate climatic factors during rainy season like high temperature and humidity. The mean RR was higher in June, September, and October (96, 92, and 91 breaths per minute, respectively); this increase can be associated with the higher RHL and $\mathrm{T}_{\mathrm{A}}$ values recorded during these months.

The data collected in this study suggest that heat loss by cutaneous evaporation (CE) was the main heat loss mechanism triggered by the animal to sustain thermal balance. The highest average $\left(292.4 \mathrm{~W} \mathrm{~m}^{-2}\right)$ was recorded in May, when it was responsible for $90 \%$ of the heat loss, while the lowest averages were recorded in September $\left(193.2 \mathrm{~W} \mathrm{~m}^{-2}\right)$ and October $\left(200.8 \mathrm{~W} \mathrm{~m}^{-2}\right)$, when it was responsible for 85 and $83 \%$ of the total heat loss, respectively. In a tropical environment, air temperature tends to be very close to or higher than the body surface temperature, especially when animals are exposed to direct solar radiation. Under such conditions, heat loss by evaporation becomes the most efficient heat dissipation mechanism (Finch 1985; Silva 2008); thus, the ability of the animals to resist the warm environment is directly proportional to their ability to dissipate heat by the evaporative processes (Silva et al. 2002; Maia et al. 2005).

The CE values reported in the current study were greater than the $46.14 \mathrm{~W} \mathrm{~m}^{-2}$ reported by Silva and Starling (2003) for wool sheep and the $76.17 \mathrm{~W} \mathrm{~m}^{-2}$ value reported by Ligeiro et al. (2006) for goats, but it is close to the values of $350 \mathrm{~W} \mathrm{~m}^{-2}$ (Maia et al. 2005) and $240 \mathrm{~W} \mathrm{~m}^{-2}$ (Hillman et al. 2001) observed for cattle. This supports the differences that can be found in heat loss by $\mathrm{CE}$ when considering different methodologies, species, and breeds with peculiar coat traits, especially if they are exposed to different environmental conditions and types of heat exposure.

Heat loss by respiratory evaporation (RE) was higher in August $\left(29.3 \mathrm{~W} \mathrm{~m}^{-2}\right)$ in all coat color groups, representing
$11 \%$ of the total heat loss. According to Maia et al. (2005), in a hot environment, $\mathrm{CE}$ is the primary heat loss mechanism, and it is responsible for $85 \%$ of the total heat loss; the remainder occurs through RE and to a lesser degree by convection. Oliveira and Costa (2013) estimated RE in Morada Nova sheep exposed to solar radiation and found values similar to those of the present work, ranging from 12 to $38 \mathrm{~W} \mathrm{~m}^{-2}$.

In tropical environment, sensible heat transfers by convection (HC) and by radiation (R) were not efficient enough to assist the thermal equilibrium by the animal and may even have been a source of heat gain from the environment, as was observed for thermal radiation (Maia et al. 2005). The sensible heat exchange mechanisms depend on different temperatures between the body surface and the environment $(\Delta=$ $\mathrm{ST}-\mathrm{TA}$ ) and become ineffective when this temperature difference is very small or does not exist, condition that usually occurs in environments with high air temperature (Silva 2008). Thus, it is possible to realize that during all months evaluated, the convection heat loss was ineffective as a heat loss mechanism; the highest average recorded was in October but just represented 5\% only of the total heat loss. Maia et al. (2005) reported a reduction in the efficiency of the heat loss by convection when air temperature was 22 to $31{ }^{\circ} \mathrm{C}$, so that $\mathrm{HC}$ reduced from 80 to $40 \mathrm{~W} \mathrm{~m}^{-2}$.

The heat transfer by radiation (R) was a heat gain mechanism in all months. The highest averages were reported in April $\left(242.9 \mathrm{~W} \mathrm{~m}^{-2}\right)$, September $\left(242.6 \mathrm{~W} \mathrm{~m}^{-2}\right)$, and October $\left(239.2 \mathrm{~W} \mathrm{~m}^{-2}\right)$, corresponding to the dry season, with high radiant heat loads. In tropical regions, the mean radiant temperature is usually close to or higher than the body surface temperature (Collier and Gebremedhin 2015), so animals tend to gain heat by thermal radiation due to the negative temperature gradient between the coat surface and the mean radiant temperatures ( $\Delta=\mathrm{ST}-\mathrm{TRM})$. Maia et al. (2014) reported that animals exposed to solar radiation absorb eight times 
more thermal radiation when compared with animals in the shade, regardless of coat color.

All animals maintained homeothermy, and no significant differences were found for RT among the groups within RHL, according to Fig. 1. Dark-red animals showed greater variation in RT on average within RHL classes $\left(38.6\right.$ to $39.5{ }^{\circ} \mathrm{C}$ ), which can be a result of an increased heat gain resulting in greater body temperature. The white-coated animals showed lower RT variation, and even under almost double RHL, they could maintain a constant RT. This result may be a good indication of homeothermy. Silanikove (2000) reported that RT and respiratory rate were the main characteristics to be monitored in animals exposed to hot environments. Gebremedhin et al. (2008) describe the RT as the most reliable indicator to measure heat stress.

As for the surface temperature (ST), significant differences were observed among the coat color groups under different RHL classes. White-coated animals showed lower average ST than those of other groups (Fig. 1); this result can be explained by the higher reflectivity of the white coat, resulting in lower absorption rate of solar radiation by the animals. Hansen (2004) found higher reflectance values in white-coated animals than those in dark-coated ones. Silva et al. (2003) evaluated the transmittance $(\rho)$ in different coat colors and observed that in animals with white coats, the value of $\rho$ was higher than that in animals with red coats, at wavelengths of 300-850 nm. In this context, a darker coat tended to absorb more radiant energy, thus becoming warmer than the white ones (Finch et al. 1984). Thus, white ewes can be more advantageous under extensive systems, especially considering that they have darkly pigmented skin, because the ultraviolet (UV) radiation is easily transmitted through the white coat and then blocked by the melanin-pigmented skin (Silva et al. 2003).

Red-coated ewes showed values of surface temperature very close to the air temperature, resulting in a smaller thermal gradient between body surface and atmosphere $\left(\Delta=\mathrm{TS}-\mathrm{T}_{\mathrm{A}}\right)$, especially in RHL classes below $800 \mathrm{~W} \mathrm{~m}^{-2}$, resulting in lower heat losses by convection in this group of animals. However, when the RHL was above $800 \mathrm{~W} \mathrm{~m}^{-2}$, the body surface temperature was higher, thus resulting in a higher thermal gradient; in such circumstances, heat loss by convection (HC) was higher (Fig. 1). White-coated animals presented statistically higher $\mathrm{HC}$ values in almost all RHL classes, compared to other groups. However, red animals showed no significant differences for this trait. Other factors, such as the wind speed, may influence $\mathrm{HC}$; wind speed may have been higher in herd 3, with white-coated animals. Maia et al. (2014) studied black and white goats exposed to direct sunlight and found values of $\mathrm{HC}$ higher than those of the present study, in which the lowest value was $50 \mathrm{~W} \mathrm{~m}^{-2}$ and the largest one $130 \mathrm{~W} \mathrm{~m}^{-2}$. Thus, it could be assumed that, in the conditions of the present study, $\mathrm{HC}$ was not significant for heat loss by animals.

In relation to heat transfer by radiation, all groups gained heat due to the negative temperature difference between coat surface and mean radiant temperatures. Under equatorial regions' climate conditions, the temperature difference between the body surface and the ambient temperature is very low, which results in a low efficiency of sensible heat loss. The animals gained heat by $\mathrm{R}$ and lost only a small fraction of it through HC. It was expected that the dark-coated animals had greater heat gain by $\mathrm{R}$, but the results of the present study showed that the heat gain by radiation was higher in whitecoated animals because of the large differences between ST
Fig. 1 Means of coat surface temperature, rectal temperature, heat loss by convection, and heat gain by radiation, as a function of radiant heat load class of different coat color groups: (1) dark red coat, (2) red coat with intermediate tonality, (3) light-red coat, and (4) white coat, of Morada Nova sheep in the semiarid region of northeastern Brazil

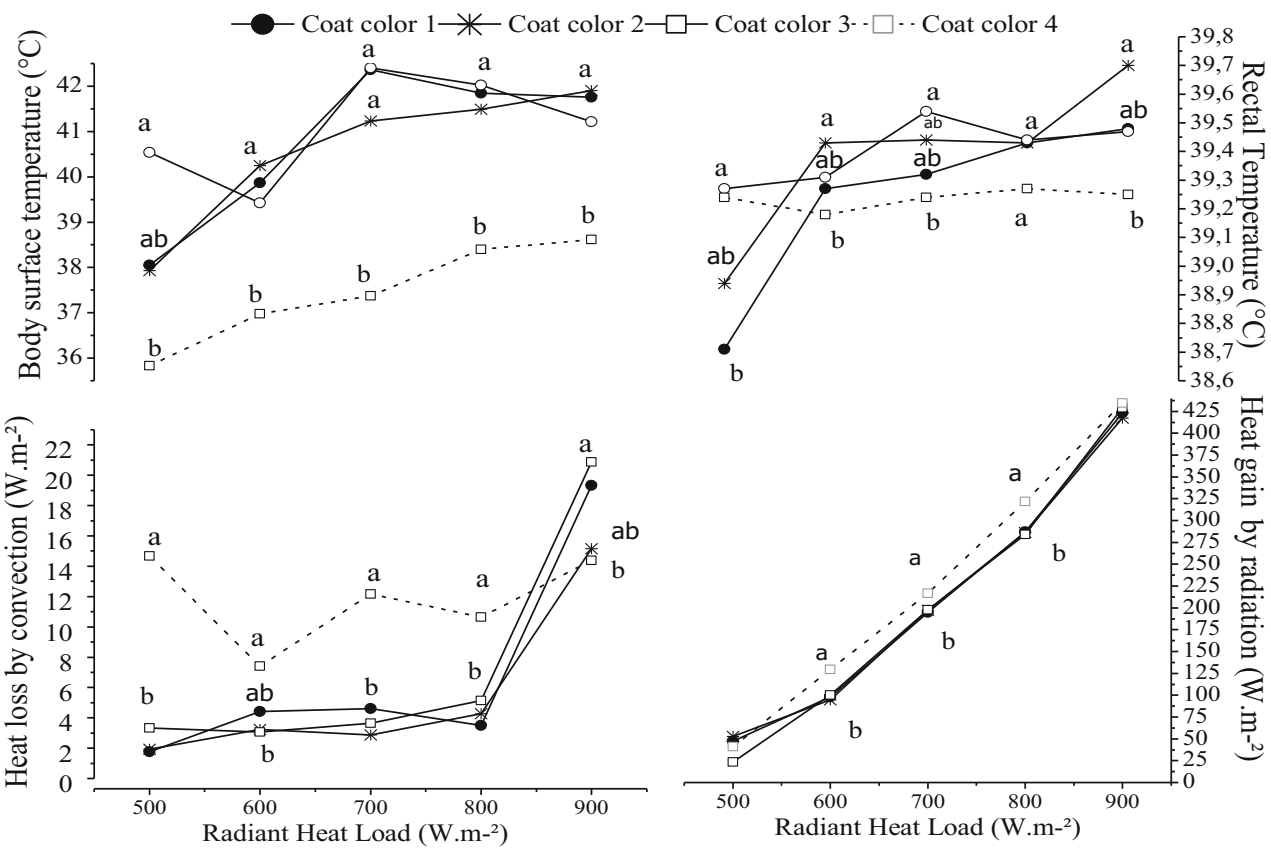


and MRT; in red-coated animals, the gradient was smaller, which resulted in a less gained radiation. When RHL was above $800 \mathrm{~W} \mathrm{~m}^{-2}$, the heat gain by radiation was similar for all shades of coats (Fig. 1). Therefore, the protection of animals against direct sunlight is the best method of reducing heat gains by radiation, regardless of the coat color of animals.

Fadare et al. (2012) found different results, in which the black animals had higher heat gain by radiation, resulting in highest means of RT and RR than those of the white ones.

There was a significant difference in relation to $\mathrm{RR}$, among groups, according to RHL (Fig. 2); in an environment of 500 $\mathrm{W} \mathrm{m}{ }^{-2}$ RHL, there were no significant differences between groups. However, in the $600 \mathrm{~W} \mathrm{~m}^{-2}$ RHL class, white-coated animals showed a lower average of RR. Animals with the red coat color of different shades showed no significant differences in relation to RR, indicating the homogeneity of the red population for the absorption of radiation and the body warming necessary to activate RR. All groups showed an increase of RR under the highest RHL classes, and this increase was more pronounced in animals with the red coat color, regardless of shade, which showed an increased by $107 \%$ RR when RHL changed from 500 to $900 \mathrm{~W} \mathrm{~m}^{-2}$. This behavior was not observed in white animals, which, even when exposed to the same RHL class as the other groups, showed less variation in RR, from 59 to 68 breaths/min, an increase of only $15 \%$ over the radiation extremes. Increasing RRs as a response by animals to heat stress has been studied widely (Panagakis 2011) and is considered a very important mechanism to cope with stressful situations, especially in sheep because it is a panting species. Srikandakumar et al. (2003) evaluated two different genetic groups that presented important increases in respiratory thermolysis and observed higher magnitudes in RR in black coat (128/min) than those in white animals $(68 / \mathrm{min})$ exposed to the same heat stress conditions; the lower magnitude of increase in RR suggests that the latter breed was less stressed by high air temperature.
McManus et al. (2009) observed a similar behavior in Santa Ines sheep, with lower RR exhibited by white animals when compared with brown and black animals or Bergamasca breed of sheep.

The over-heating of the body surface of animals can result in increased cutaneous evaporation (Dmi'el and Robertshaw 1983; Silva and Maia 2011; Silva et al. 2012). It is expected that animals with darker coats present higher $\mathrm{CE}$ values than those with white coats, due to the higher heating of the dark coat. However, this trend was not found in the present study. White coats had lower temperatures but had higher CEs under an RHL of $600 \mathrm{~W} \mathrm{~m}^{-2}$ and above; however, no significant differences were observed in $\mathrm{CE}$ among groups, under RHL $\leq 500 \mathrm{~W} \mathrm{~m}^{-2}$ (Fig. 2). Costa et al. (2014) found similar results, in which black goats had the highest surface temperature values, while the white-coated ones showed high CE, suggesting that the heat loss by cutaneous evaporation cannot be simply explained by a higher body surface temperature and that other factors are associated with $\mathrm{CE}$, such as the number and functionality of the sweat glands (Nay and Hayman 1956) and some physical coat characteristics. Finch et al. (1982), for example, mentioned that rectal temperature was the most important characteristic for activating the $\mathrm{CE}$, compared to the ST in the specific conditions of their experiment.

Cutaneous evaporation decreased when RHL increased (Fig. 2). This result is totally contradictory with the results in the literature for other species evaluated under temperate conditions. However, almost all studies found in the literature reported the thermoregulation of animals from temperate climates, in higher latitude environments, where annual and daily changes in thermal conditions can result in expected responses. On the other hand, the present findings can perhaps show that Brazilian non-wool breeds have a particular pattern of thermoregulation under high radiation exposure. Our findings agree with Silva et al. (2017), who found similar results in Morada Nova ewes under heat stress during a 24-h period
Fig. 2 Means of cutaneous evaporation and respiratory rate of Morada Nova sheep in Brazil semiarid region, as function of radiant heat load class of different coat colors. Coat color $1=$ darkred coat, coat color $2=$ red coat with intermediate tonality, coat color 3 = light-red coat, and coat color $4=$ white-coated animals totally white

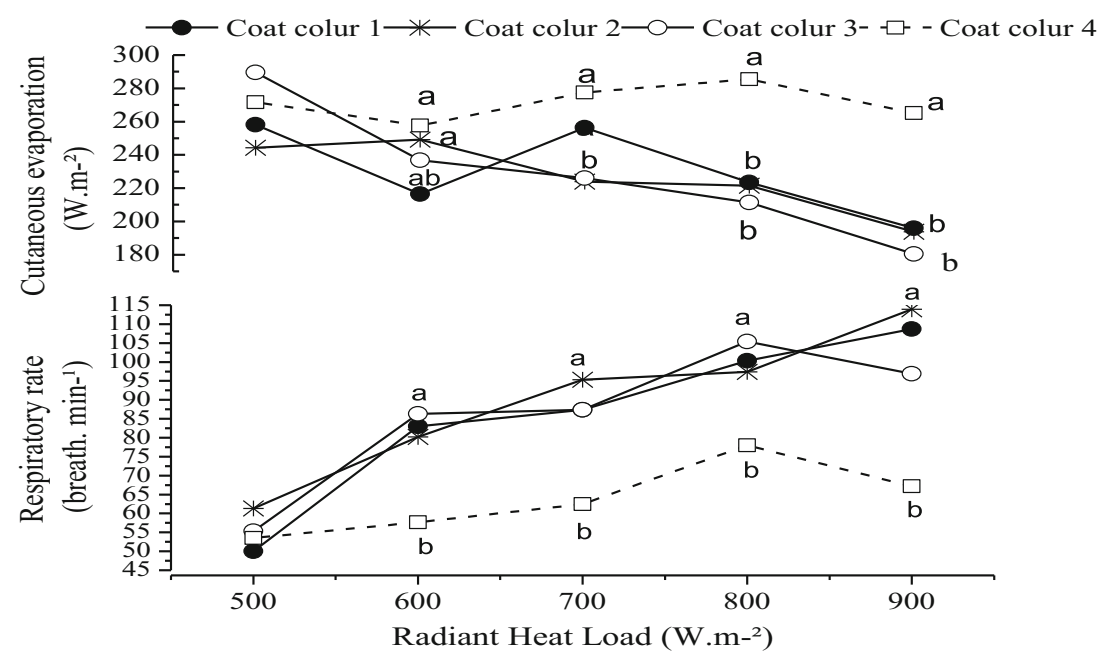


when the animals exhibited higher sweating rates during the nighttime. In environmental factors represented by heat stress, the animals used respiratory rate more intensively; the RR increased nearly $556 \%$ from nighttime to daytime (21 to 142 breaths $\mathrm{min}^{-1}$ ), and sweating rate increased only $18 \%$ (30.84 to $44.48 \mathrm{~g} \mathrm{~m}^{-2} \mathrm{~h}^{-1}$ ) causing the authors to suggest that the increase of RR allowed a substantial amount of heat to be lost, and, possibly for that reason, the animals did not sweat intensively during the daytime.

The logistic regression analysis showed that animals with dark-red coats had higher RRs, with $79.74 \%$ of the animals having RRs above 60 breaths $\min ^{-1}$, while white-coated animals triggered this mechanism less and only $52.6 \%$ had RRs above the value considered to be stressed (Fig. 3). Silanikove (2000) reported that this variable can quantify the severity of the stress to which the animals are exposed, such that a RR up to 60 breaths $\mathrm{min}^{-1}$ is considered low stress, and a RR above this value is considered medium and high stress. For RT, all animals, regardless of coat color shade, maintained values within the normal range for sheep $\left(38.3\right.$ to $39.9^{\circ} \mathrm{C}$ ), and only $17 \%$ of the animals of group 1 had RTs above $39.9^{\circ} \mathrm{C}$, and only $10 \%$ of the white animals showed RTs above $39.9^{\circ} \mathrm{C}$. All groups of animals were able to maintain homeothermy.

In the present study, there were differences found in the RR among the groups, such that the red coat triggered RR as an intense response to heat stress, possibly due to increased body heating; on the other hand, white animals had more intense heat losses by cutaneous evaporation without raising RR to maintain thermal balance, which may be due to a lower heating of this group of animals. However, all the animal groups could maintain homeothermy regardless of the mechanism used. Rai et al. (1979) evaluated RR and CE in different breeds and crosses of sheep and observed an increase of $500 \%$ in the RR of Rambouillet animals when the air temperature ranged from 20 to $42{ }^{\circ} \mathrm{C}$, but under the same environmental conditions, these animals had less $\mathrm{CE}$ than the other groups.

Currently, there is an intense selection system for Morada Nova animals, based on racial characteristics, such as coat color, ear size, and the pigmentation of hooves and nasal mirror (ARCO 2016). The result of such methods is the reduction in genetic variability within the flocks of the breed. Shiotsuki et al. (2016) evaluated breed selection criteria and realized that the animals are primarily selected based on external characteristics such as coat color pigment of the hulls and the absence of horns, for example, which are characteristics that are associated with low birth weights of the animals.

The red-coated animals with dark and light tonality, as well as the white-coated ones, are commonly discarded in most of the farming systems, with the justification that they are less well adapted to the semiarid conditions. The present study is the first to evaluate the main thermoregulatory mechanisms of Morada Nova sheep with different coat colors exposed to direct solar radiation; it could be said that the red-coated animals, regardless of tonality, do not show differences in relation to the mechanisms used to maintain homeothermy. These results reject the assumption that the animals with dark-red or light-red coats are less well adapted to a hot environment. White-coated animals were also able to maintain thermal balance when exposed to the same levels of solar radiation as the red animals. These results confirm the adaptive ability of Morada Nova sheep, regardless of the coat color and subbreed groups. Leite et al. (2017) evaluated 383 adult Morada Nova ewes, observed the influence of the coat characteristics on some indicators of homeostasis, and realized that the reduction of tyrosine concentration was directly related to physical coat traits and not to coat color. Costa et al. (2015) evaluated the physiological characteristics of white and red Morada Nova ewes and realized that both groups were able to maintain normal blood indicators such as biochemical levels and blood counts, but that the red-coated population needs greater adjustments in order to maintain homeothermy. In addition, the white population always has better body condition during the year, thus confirming that besides being well adapted, it has also great potential to be utilized under Brazilian semiarid climate conditions and should, therefore, be conserved and multiplied.
Fig. 3 Logistic regression of rectal temperature (RT) and respiratory rate $(\mathrm{RR})$, per coat tonality in Morada Nova sheep in an equatorial semiarid region

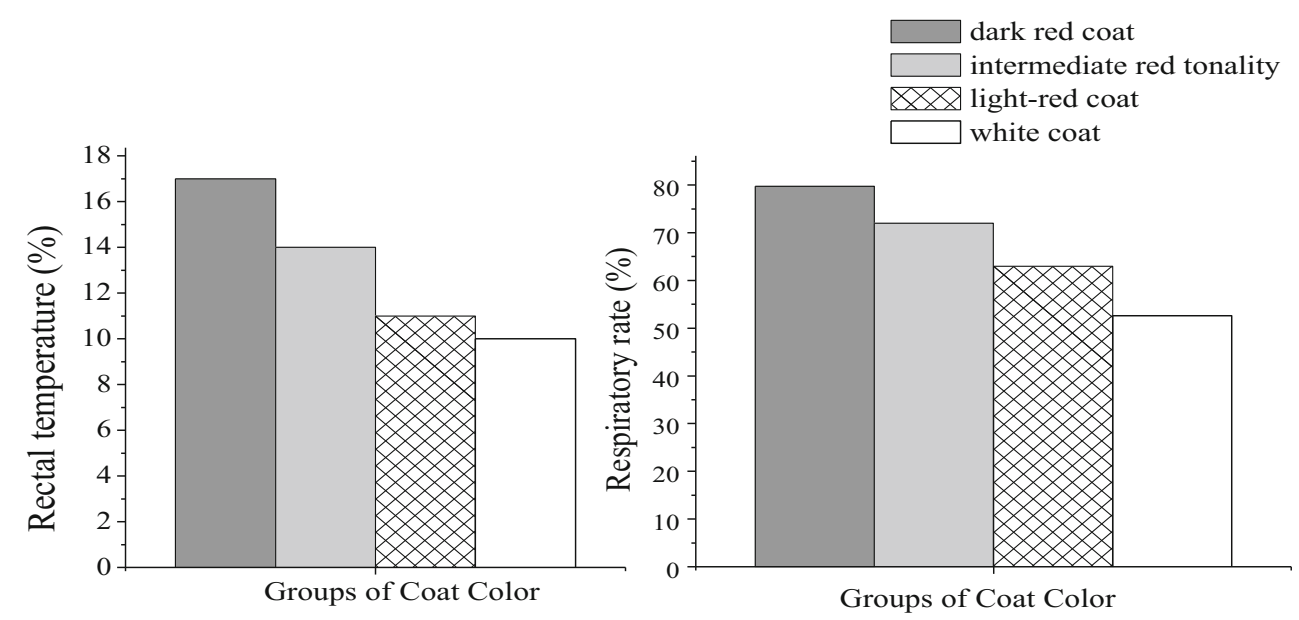


Finally, it is possible to say that the results of this study can help the Morada Nova breeders to adopt selection and management strategies to improve the performance of the breed, thus preventing its risk of extinction. This is a more drastic problem for the white population, of which there are only five recognized commercial flocks, which had been proven to be important sources of genetic material adapted to hot environmental conditions.

\section{Conclusion}

The differences in the activation of the thermoregulatory mechanisms varied according to the coat color; however, all groups maintain the homeostasis conditions. The hypothesis that there are differences in adaptive capacity according to coat color can be discarded, so all animals can be used in production systems, a fact that can lead to a greater genetic variability of livestock.

The white-coated population represents an excellent locally adapted resource in the semiarid region of Brazil and must be preserved and multiplied since they have good adaptive responses to the environment with high levels of solar radiation.

Acknowledgments The authors acknowledge EMBRAPA - Goat and Sheep and Capes - Ciência sem Fronteiras Program - Visiting Researcher project (process number $n^{\circ} 88881030352 / 2013-1$ ) for the financial support.

\section{References}

ARCO (2016) Padrão racial de ovinos Morada Nova. Associação Brasileira de Criadores de Ovinos. Bagé, Brazil (available at http:// www.arcoovinos.com.br)

Bennett JW (1973) Regional body surface area of sheep. J Agric Sci 81: $429-432$

Bianca W, Kunz P (1978) Physiological reactions of three breeds of goats to cold, heat and high altitude. Livestock Prod Sci 5:57-69

Broucek J, Kisac P, Uhrincat M (2009) Effect of hot temperatures on the hematological parameters, health and performance of calves. Int J Biometeorol 15:201-208

Churchill SW, Bernstein M (1977) Correlating equation for forced convection from gases and liquids to a circular cylinder in crossflow. $\mathrm{J}$ Heat Transf 94:300-305

Collier RJ, Gebremedhin KG (2015) Thermal biology of domestic animals. Annu Rev Anim Biosci 3:515-532

Correa MPC, Cardoso MT, Castanheira M, Landim AV, Dallago BSL, Louvandini H, McManus C (2012) Heat tolerance in three genetic groups of lambs in central Brazil. Small Rumin Res 104:70-77

Costa CCM, Maia ASC, Fontenele Neto JD, Oliveira SEO, Queiroz JPAF (2014) Latent heat loss and sweat gland histology of male goats in an equatorial semi-arid environment. Int J Biometeorol 58:179-184

Costa WP, Façanha DAE, Leite JHGM, Silva RCB, Souza CH, Chaves DF, Vasconcelos AM, Soto-Blanco B, Vale AM, Pimenta Filho EC (2015) Thermoregulatory responses and blood parameters of locally adapted ewes under natural weather conditions of Brazilian semiarid region. Semina: Ciências Agrárias 36:4589-4600
Dmi'el R, Robertshaw D (1983) The control of panting and sweating in the black Bedouin goat: a comparison of two modes of imposing a heat load. Physiol Zool 56:404-411

Facó O, Paiva SR, Alves LRN, Lobo RNB, Villela LCV (2008) Raça Morada Nova: Origem, Características e Perspectivas, 1st edn. Embrapa Caprinos e Ovinos, Sobral-Ceará, Brasil (Documentos 75)

Fadare AO, Peters SO, Yakubu A, Sonibare AO, Adeleke MA, Ozoje MO, Imumorin IG (2012) Physiological and haematological indices suggest superior heat tolerance of white-coloured West African Dwarf sheep in the hot humid tropics. Trop Anim Health Prod 45(1):157-165

Finch VA (1985) Comparison of non-evaporative heat transfer in different cattle breeds. Aust J Agric Res 36:497-508

Finch VA, Bennett IL, Holmes CR (1982) Sweating responses in cattle and its relation to rectal temperature, tolerance of sun and metabolic rate. J Agric Sci 99:479-487

Finch VA, Bennett IL, Holmes CR (1984) Coat color in cattle: effect of thermal balance, behavior and growth and relationship with coat type. J Agric Sci 102:141-147

Gebremedhin KG, Porter WP, Cramer CO (1983) Quantitative analysis of heat exchange though the fur layer of Holstein calves. Trans ASAE 26:188-193

Gebremedhin KG, Hillman PE, Lee CN, Collier RJ, Willard ST, Arthington JD, Brown-Brandl TM (2008) Sweating rates of dairy cows and beef heifers in hot conditions. Trans ASABE 51(6):21672178

Hahn GL (1985) Management and housing of farm animals in hot environments. In: Yousef M (ed) Stress physiology in livestock. CRC Press, Boca Raton, pp 151-174

Hales JRS, Webster MED (1967) Respiratory function during thermal tachypnea in sheep. J Physiol 190:241-260

Hansen PJ (2004) Physiological and cellular adaptations of zebu cattle to thermal stress. Anim Reprod Sci 82:349-360

Hillman PE, Lee CN, Parkhurst A (2001) Impact of hair color on thermoregulation of dairy cows to direct sunlight. In: Annual International Meeting of the ASAE. Sacramento. Paper $n^{\circ} 014301$

Leite JHGM, Façanha DAE, Costa WP, Chaves DF, Guilhermino MM, Silva WST, Bermejo LA (2017) Thermoregulatory responses related to coat traits of Brazilian native ewes: an adaptive approach. J Appl Anim Res 46:353-359. https://doi.org/10.1080/09712119.2017. 1302877

Ligeiro EC, Maia ASC, Silva RG, Battiston CM (2006) Heat loss by cutaneous evaporation associated to morphological characteristics of hair coat in dairy goats raised in a tropical environment. Rev Bras Zootec 35:544-549

Lôbo RNB, Pereira IDC, Facó O, McManus CM (2011) Economic values for production traits of Morada Nova meat sheep in a pasture based production system in semi-arid Brazil. Small Rumin Res 96:93-100

Maia ASC, DaSilva RG, Battiston Loureiro CM (2005) Sensible and latent heat loss from body surface of Holstein cows in a tropical environment. Int J Biometeorol 50:17-22

Maia ASC, DaSilva RG, Nascimento ST, Nascimento CCN, Pedrosa HP, Domingos HGT (2014) Thermoregulatory responses of goats in hot environments. Int J Biometeorol 59:1025-1033

Marai IFM, El-Darawany AA, Fadiel A, Abdel-Hafez MAM (2007) Physiological traits as affected by heat stress in sheep - a review. Small Rumin Res 71:1-12

Mariante AS, Albuquerque MSM, Egito AA, Paiva SR, Castro STR (2005) Conservação de raças brasileiras ameaçadas de extinção e a importância de sua inserção em sistemas de produção. Agrociência IX(2):459-464

McLean JA (1963) The partition of insensible loss of body weight and heat from cattle by ventilated capsules. Int J Biometeorol $167: 427-477$ 
McManus C, Paludo GR, Louvandini H, Gugel R, Sasaki LCB, Paiva SR (2009) Heat tolerance in Brazilian sheep: physiological and blood parameters. Trop Anim Health Prod 41:95-101

Morais DAEF, Maia ASC, Silva RG, Vasconcelos AM, Lima PO, Guilhermino MM (2008) Variação anual de hormônios tireoideanos e características termorreguladoras de vacas leiteiras em ambiente quente. R Bras Zootec 37:538-545

Nay T, Hayman RH (1956) Sweat glands in zebu (Bosindicus) and European (Bos Taurus) cattle. I. Size of individual glands, the denseness of their population and their depth below the skin surface. Aus J Agric Res 7:482-495

Oliveira SEO, Costa CCM (2013) Respiratory heat loss in Morada Nova sheep in Brazilian semi-arid regions. J Anim Behav Biometeorol 1: $17-20$

Panagakis P (2011) Black-globe temperature effect on short-term heat stress of dairy ewes housed under hot weather conditions. Small Rumin Res 100:96-99

Rai AK, Singh M, More T (1979) Cutaneous water loss and respiration rates of various breeds of sheep at high ambient temperatures. Trop Anim Health Prod 11:51-56

Santos JRS, Souza WH, Cezar MF, Tavares GP (2006) Respostas fisiológicas e gradiente térmicos de ovinos das raças Santa Inês, Morada Nova e seus cruzamentos com a raça Dorper as condições do Semiárido nordestino. Ciênc Agrotecnol 20:995-1001

Sevi A, Rotunno T, DiCaterina R, Muscio A (2002) The fatty acid composition of exe milk, as affected by solar radiation under high ambient temperature. J Dayre Sci 69(2):181-194

Shiotsuki L, Silva PHT, Silva KM, Landim AV, Morais OR, Facó O (2016) The impact of racial pattern on the genetic improvement of Morada Nova sheep. Animal Genetic Resources, Food and Agricultural Organization of the United Nations, p 1-10
Silanikove N (2000) Effects of heat stress on the welfare of extensively managed domestic ruminants. Livest Prod Sci 67:1-18

Silva RG (2008) Biofísica ambiental: os animais e seu ambiente. FUNEP, São Paulo-Brasil

Silva RG, Maia ASC (2011) Evaporative cooling and cutaneous surface temperature of Holstein cows in tropical conditions. R Bras Zootec 40:1143-1147

Silva RG, Starling JMC (2003) Evaporação cutânea e respiratória em ovinos sob altas temperaturas ambientes. Rev Bras Zootec 32: 1956-1961

Silva RG, LaScala N Jr, Lima Filho AE, Catharin MC (2002) Respiratory heat loss in the sheep: a comprehensive model. Int J Biomeorol 46: 136-140

Silva RG, LaScala N Jr, Tonhati H (2003) Radiative properties of the skin and hair coat of cattle and another animals. Trans ASAE 46:913918

Silva RG, Guilhermino MM, Façanha-Morais DAE (2010) Thermal radiation absorbed by dairy cows in pasture. Int J Biometeorol 54:511

Silva RG, Maia ASC, Costa LLM, Queiroz JPAF (2012) Latent heat loss of dairy cows in an equatorial semi-arid environment. Int $\mathrm{J}$ Biometeorol 56:927-932

Silva WE, Leite, JHGM, Souza, JER, Costa WP, Silva WST, Guilhermino, MM, Bermejo LA, Façanha, DAE (2017) Daily rhythmicity of the thermoregulatory responses of locally adapted Brasilian sheep in a semiarid environment. Int J Biometeorol 61(7):1221-1231. https://doi.org/10.1007/s00484-016-1300-2

Srikandakumar A, Johnson EH, Mahgoub O (2003) Effect of heat stress on respiratory rate, rectal temperature and blood chemistry in Omani and Australian Merino sheep. Small Rumin Res 49:193-198

Swenson MJ, Reece OW (1996) DUKES. Fisiologia dos Animais Domésticos, 11th edn. Guanabara, Rio de Janeiro, p 856 